\title{
Incorrect, Inadequate or Imprecise Result or Readings
}

National Cancer Institute

\section{Source}

National Cancer Institute. Incorrect, Inadequate or Imprecise Result or Readings. NCI

Thesaurus. Code C62848.

Problem associated with a nonconforming end result, data, or test results provided by the device to its performance specifications. 